\title{
The Influence of Packaging and Information Transparency on Intention to Try with Endorser Capability as Moderation
}

\author{
Auditia Setiobudi1) \\ auditia.setiobudi@ciputra.ac.id \\ Deandra Vidyanata ${ }^{2)}$ \\ deandra.vidyanata@ciputra.ac.id \\ Clarissa Sabella ${ }^{3)}$ \\ csabella@student.ciputra.ac.id \\ 1)2)3)Ciputra University Faculty of Business Management
}

\begin{abstract}
Food and beverage industry is growing rapidly which causes companies to trying to fullfil consumer needs, one of which is packaging. Packaging is an important element to protect the product. Technological advances are able to make it easier for everyone to get information. Transparency information is able to provide information that consumers need. The purpose of this research is to examine the effect of packaging and information transparency on the intention to try Cikake products and to examine the moderating effect of endorser capability between information transparency on intention to try Cikake's. The population of this research is Cikake consumers who have tried this product before, have an Instagram account and live around the city of Pandaan. The sampling method used in this study was the census method, with a population of 100 people as the sample. Respondent data is collected by distributing questionnaires to Cikake consumers. This research uses Moderated Multiple Regression (MMR) as an analysis tool. The finding from the results of multiple linear regression tests which resulted in a significance value on the packaging variable of 0.005 while the information transparency variable was 0.000 , which means that packaging and information transparency had an effect on the intention to try. The effect of moderation has a significance value of 0.030 and an increase in the coefficient of determination, which means that endorser capability is able to moderate the relationship of information transparency to intention to try Cikake's.
\end{abstract}

Keywords: packaging, information transparency, endorser capability, intention to try 


\section{PRELIMINARY}

Business is very diverse and comes from various industries. Not only large industries that contribute to Gross Domestic Product but Micro Small and Medium Enterprises businesses are starting to give signs of progress and participate in competing competitively. The President of the Republic Indonesia said that Micro Small and Medium Enterprises can support the Indonesian economy. The food and beverage industry is currently the mainstay of the industry in all sectors and has an impact on economic growth. The food and beverage industry continues to increase every year. In 2020, the food and beverage industry is predicted to experience an increase of $1 \%$ in the third quarter. This increase could occur due to an increase in people's purchasing power.

Food that is needed now is food that is practical and fast in its presentation such as ready-to-eat food, processed food or food that is packaged in the form of ricebowl. Changes in people's lifestyles have begun to change due to busy work which makes workers order practical food more often than eat at home. Cikake is a business engaged in the food industry serving rice topped with chicken and various variants of spices. This business was founded in 2018 and opened a stand in 2019 until now in Pandaan. Cikake product is using ricebowl packaging.

Cikake uses the packaging to take product photos as a way of promotion on Instagram. According to Jovita (2017), social media is not only used for media to communicate but also to get information. Social media has an important role as a medium to communicate and disseminate information openly, one of which is information about existing promos. Instagram is included in the mass media that is able to have a different impact on everyone who sees it and their point of view.

Endorsement is the use of an artist or blogger to review existing products by uploading these products on their social media accounts. Utilizing endorsements in promoting a product is one form of communication in marketing communication (Hardilawati et al., 2019). Endorsers must have the ability to understand a product that will be offered, this ability can come from the knowledge or information that the endorser has at the time of advertising in the public. In addition to reviewing and explaining a product, endorsers provide directives to followers who follow them to see Instagram about the products being promoted, so that their Instagram must have clear and open information to attract consumers to visit Instagram.

\section{LITERATURE REVIEW}

\section{Priming Theory}

Priming theory according to Ritonga (2018), the process of mass media becomes an object by focusing on some issues and not on other issues, and mass media is able to have an impact, namely changing the evaluation standards to assess the social reality at hand. Primming's theory emphasizes that there is an impact or influence from a media that is able to remind the public or provide more information about something so that it can trigger more attention. According to Alger (1989), the Priming theory was built from the assumption of people who did not make any considerations so as to be able to present a person's decision to take an action. 


\section{Packaging}

Packaging is an element that is able to effectively influence consumer assessment of a product. Murfeni (2016) states that packaging is all activities that design and produce a container for a product. Packaging must have a function as protection and attraction. according to Teofilus et al., (2019) there are five packaging variable indicators; (a) easy to open: packaging that is easy to open without the need for scissors; (b) safe in storage: packaging is able to store products that do not run out during the consumption process. ensure that it has safe packaging and that the product doesn't spill easily; (c) easy to prepare: packaging that is easy to prepare, has the advantage that consumers can pour the contents of the product out of the packaging easily; (d) easy in the consumption process: Has packaging in plastic form to facilitate the consumption and cooking process; (e) easy to carry: packaging has practical properties, is light and strong in durability.

\section{Information Transparency}

Online B2B (business to business) provides data on prices and costs resulting in more transparent information in electronic media. Company owners must be able to maintain a balance between transparency of company information with confidentiality of data to minimize intense competition between companies but still be able to take advantage of collaborative information transparency and the importance of information transparency in e-commerce must be considered (Teofilus et al., (2020). There are indicators of information transparency according to Stohl et al., (2016): (a) product transparency, can be in the form of transaction transparency and vendor transparency can affect transparency in information; (b) perceived information transparency, able to increase consumer intentions in seeing products offered online ; (c) risk perception, which is generated by consumers due to the transparency of open information.

\section{Endorsement Capability}

Advertising can be a thing that attracts the center of attention by being able to use a celebrity or figure as a medium to attract consumers by having an attachment between the advertised products. Celebrity expertise in endorsements has the main reason for choosing celebrity endorsements as a medium that supports the advertising promotion process. Endorsement celebrities who have certain insights and issues such as understanding and being reliable about the brand are able to convince others to take action (Mubarok, 2016). There are several indicators of celebrity endorsers according to Kertamukti (2015: 70): (a) visibility, the dimension of how famous a celebrity is, how popular the celebrity is, so you can see the number of fans that celebrity endorsers have and how often they appear in the public; (b) credibility, an endorser who can be trusted and has expertise is the main reason for choosing celebrity endorsers as a promotional media. Able to convince others to take decisions into action; (c) power, a celebrity endorser must have power when doing advertising by instructing consumers and considering a product. 


\section{Intention to Try}

Intention is an attitude to try and a social norm to try. According to Bagozzi \& Dholakia (2002), consumers who have behavioral intentions prefer to have behavioral goals in many situations and must make efforts to meet the desired goals. Individuals who will try a product are based on the intention that comes from the individual himself to achieve the desired results. There are several indicators of intention to try according to Hinz and Ployhart (1998): (a) attitude toward trying: describing individual reasons for trying something. Can be measured by the goodness associated with efforts to achieve the desired result; (b) subjective norms: individual perceptions of the importance of people's thoughts. Social influence that affects individuals in their behavior.

\section{Previous Reseacrh}

Research conducted by Hani et al., (2018) entitled "The effect of celebrity endorsement on consumer behavior: Case of the Lebanese Jewelry Industry". The result of the research is that using endorser support can provide an attraction that has a positive effect on consumer memory, the products used by endorsers provide attractiveness and interest to consumers when they first see the product. The endorser's mastery of information is one of the supporting factors in generating perceptions.

The second research, conducted by Imiru (2017) with the title "The Effect of Packaging Attributes on Consumer Buying Decision Behavior in Major Commercial Cities in Ethiopia". The result of this research is that the more frequent relationships with consumers will increase consumer confidence in a product. Increasing openness is also a factor in consumers seeing a product.

The third research, conducted by Adiyanto (2019) entitled "Development of Food Packaging Design With Kansei Engineering Approach". The result of this research is that packaging is one of the most important focuses in developing food because packaging is able to give the first impression to consumers when they see the packaging design for the first time and the convenience of packaging during the consumption process.

The fourth research conducted by Purwanto (2017) entitled "Buying Behavior of Fashion Products Based on Trust Using Social Media". The result of this research is that the more frequent relationships with consumers will increase consumer confidence in a product. Increasing openness is also a factor in consumers seeing a product.

The fifth research conducted by Farid \& Dimeila (2019) was entitled "The Influence of Celebrity Endorsers on Instagram on Buying Interest of Followers". The research conducted shows that respondents who follow @awkarin see endorsement product posts and get information that can influence followers' desire to have similar products..

\section{Hypothesis}

H1 = Packaging affects Intention to Try Cikake

$\mathrm{H} 2=$ Transparency Information affects Intention to Try Cikake

H3 = Transparency Information affects Intention to Try with Endorser 
Capability as moderation

\section{RESEARCH METHOD}

This study uses a quantitative method by distributing questionnaires to consumers who have bought Cikake products at least once. Quantitative research is data in the form of numbers or scoring. The population that will be used in this research is Cikake's Instagram followers. The sampling technique used in this study was purposive sampling method. This technique provides criteria, the criteria to be used in this study are as follows: (a) Have purchased Cikake at least once; (b) have an Instagram account; (c) residing around the city of Pandaan.

Samples in the study using the Slovin formula and obtained 100 respondents. The research scale used is to use a Likert scale (1-5). The method of distributing this questionnaire will be done using google form. The data analysis used is the multiple regression analysis method using the SPSS tool. To perform moderation testing using Moderated Multiple Regression (MMR). Moderated Multiple Regression (MMR) is a method used to determine the proportion of the variables described by two or more variables using moderator variables (Rochyawati, 2017).

\section{RESULT AND DISCUSSION}

\section{Respondent Characterictics}

In terms of gender, it is said that women are more dominant, meaning that Cikake consumers are mostly women. Based on gender, it is expected to be able to describe the phenomena contained in this study well. Differences in gender comparisons can occur because women tend to have a higher sense of curiosity so that they have the desire to try food outside. The age range was dominated by 74 respondents aged 17-27 years. This is because the 17-27 year olds tend to like modern food and prefer practical food that is packaged in a bowl. At the age of 17-27 years, consumers have a flexible level of openness to a product. Based on the location of residence, it can be concluded that the most Cikake consumers are in Pandaan City, this is because the Cikake location is located in the middle of Pandaan City, making it easier for consumers located in Pandaan City to reach.

\section{Validity}

The test results for the validity of the packaging variable, information transparency, endorser reliability and intention to try on all items have requirements that match the overall significance value of 0.000 , which means that all items in this research variable are declared valid. Comparing the pearson correlation of all variables with $r$ table, the value of $r$ table for respondents of 100 is 0,1946 . All variables have a pearson correlation greater than 0.1946 , so the statement on each variable is valid.

\section{Reliability}

Cronbach alpha variable packaging is 0.800 , information transparency is 0.786 , endorser capability is 0.800 and intention to try is 0.810 , which means that all items exceed the minimum requirement of Cronbach alpha above 0.6. Seeing the value of cronbach alpha if the deleted item has a value below the overall Cronbach alpha, 
the item used is reliable. In the corrected item-correlation column, it has a minimum requirement of 0.5 , so all items in the reliability test table are appropriate.

\section{Regression Analysis}

Table.1 Coefficients X1 \& X2

\begin{tabular}{|c|c|c|c|}
\hline \multirow{2}{*}{ Variable } & Unstandardized Coefficients & \multirow{2}{*}{ Sig. } & \multirow{2}{*}{ Result } \\
\cline { 2 - 2 } & $\mathrm{B}$ & & \\
\hline Constant & 3,123 & 0,000 & \\
\hline Packaging $(\mathrm{X} 1)$ & 0,270 & 0,014 & Significant \\
\hline Information Transparency (X2) & 0,381 & 0,019 & Significant \\
\hline
\end{tabular}

Source: Data Processed

$$
\begin{gathered}
Y=a+\beta_{1} X_{1}+\beta_{2} X_{2}+e \\
Y=3,123+0,270(X 1)+0,381(X 2)
\end{gathered}
$$

The constant in the first equation is 3.123 if the value obtained from packaging and information transparency is 0 , the value obtained for the intention to try is 3.123 . The resulting value on the packaging variable (X1) was 0.270 and information transparency $(\mathrm{X} 2)$ was 0.381 , which means that Cikake consumers' intention to try was 0.381 Cikake consumers based on Cikake's information transparency. The significance value of the packaging variable (X1) and the information transparency (X2) variable for these two variables is less than 0.05 .

Table.2 Coefficient X1, X2 \& Z

\begin{tabular}{|c|c|c|c|}
\hline \multirow{2}{*}{ Variable } & $\begin{array}{c}\text { Unstandardized } \\
\text { Coefficients }\end{array}$ & \multirow{2}{*}{ Sig. } & Result \\
\cline { 2 - 3 } & $\mathrm{B}$ & & \\
\hline Constant & 3,128 & 0,000 & Significant \\
\hline Packaging (X1) & 0,294 & 0,026 & Significant \\
\hline $\begin{array}{c}\text { Information } \\
\text { Transparency (X2) }\end{array}$ & 0,381 & 0,011 & Significant \\
\hline $\begin{array}{c}\text { Endorser Capability } \\
(\mathrm{Z})\end{array}$ & 0,325 & 0,006 & \\
\hline
\end{tabular}

Source: Data Processed

$$
\begin{aligned}
& Y=a+\beta_{1} X_{1}+\beta_{2} X_{2}+\beta_{3} Z+e \\
& Y=3,128+0.294(X 1)+0.381(X 2)+0.325(Z)
\end{aligned}
$$

The second equation is found in Table 2 which provides information about a constant of 3.128, the constant in this equation explains that if the value obtained from packaging and information transparency is 0 , the value obtained for the intention to try is 3.128. The value of the packaging variable (X1) is 0.294 and the information transparency variable $(\mathrm{X} 2)$ is 0.381 , which means that there is an interest in trying for 0.275 Cikake consumers based on information transparency. The value obtained from endorser capability $(Z)$ is 0.325 , an increase in intention to try based on the endorser 
used by Cikake. The significance value of the packaging variable (X1), the information transparency variable $(X 2)$ and the third variable endorser capability $(Z)$ had a significance value below 0.05 .

Table. 3 Coefficient $X 1, X 2, Z$ \& $(X 2 * Z)$

\begin{tabular}{|c|c|c|c|}
\hline Variable & $\begin{array}{c}\text { Unstandardized } \\
\text { Coefficients }\end{array}$ & Sig. & Result \\
\cline { 2 - 4 } & $\mathrm{B}$ & & \\
\hline Constant & 3,097 & 0,000 & Significant \\
\hline $\begin{array}{c}\text { Packaging (X1) } \\
\begin{array}{c}\text { Information Transparency } \\
(\mathrm{X} 2)\end{array}\end{array}$ & 0,297 & 0,005 & Significant \\
\hline $\begin{array}{c}\text { Endorser Capability (Z) } \\
\begin{array}{c}\text { Information } \\
\text { Cansparency } \\
\text { Capability (X2*Z) }\end{array}\end{array}$ & 0,329 & 0,000 & Significant \\
\hline
\end{tabular}

Source: Data Processed

$$
\begin{gathered}
Y=a+\beta_{1} X_{1}+\beta_{2} X_{2}+\beta 4 X_{2}{ }^{*} Z+e \\
Y=3,097+0,297(X 1)+0,182(X 2)+0,392(Z)+0,402(X 2 * Z)
\end{gathered}
$$

Based on the three multiple regression analysis, the constant value of 3.097 explains that the value obtained from packaging and information transparency is 0 , the value obtained for the intention to try is 3.097. The resulting value on the packaging variable (X1) was 0.297 , the information transparency variable (X2) was 0.182 , which means that there was an interest in trying for 0.182 Cikake consumers based on Cikake's information transparency. The value obtained from endorser capability $(Z)$ is 0.392 . The interaction of endorser capability $(Z)$ to information transparency (X2) is 0.402 which means that there is an increase in the presence of a moderating variable on the intention to try. Moderation is able to increase the intention to try Cikake products by 0.402 .

Table.4 ANOVA

\begin{tabular}{|c|c|c|}
\hline Model & F & Sig. \\
\hline 1 & 8,325 & 0,006 \\
\hline 2 & 10,516 & 0,018 \\
\hline 3 & 12,616 & 0,040 \\
\hline
\end{tabular}

Source: Data Processed

The significance value of the three equations is below 0.05 , which means that it meets the requirements for significance. Based on the results of the significance of the three models have a joint effect. The value of the first model has a significance of 0.006 , the second model is 0.018 and the third model is 0.040 . The three models can be said to be feasible and meet the Goodness of Fit Test. 
Table.5 Significance

\begin{tabular}{|c|c|c|c|}
\hline Variable & $\mathrm{t}$ & Sig. & Result \\
\hline (Constant) & 6,450 & 0,000 & \\
\hline Packaging & 4,930 & 0,005 & Significant \\
\hline $\begin{array}{c}\text { Information } \\
\text { Transparency }\end{array}$ & 3,863 & 0,000 & Significant \\
\hline Endorser Capability & 4,092 & 0,017 & Significant \\
\hline Moderation & 5,152 & 0,030 & Significant \\
\hline
\end{tabular}

Source: Data Processed

The significance value of all variables has a value below 0.05 , which means that all variables are significant. So it can be concluded that all packaging variables (X1), information transparency $(X 2)$ and endorser capability $(Z)$ as moderation have a partial effect on intention to try $(\mathrm{Y})$.

Table.6 Model Summary

\begin{tabular}{|c|c|c|}
\hline Model & $\mathrm{R}$ & $\mathrm{R}^{2}$ \\
\hline 1 & 0,315 & 0,099 \\
\hline 2 & 0,315 & 0,099 \\
\hline 3 & 0,815 & 0,661 \\
\hline
\end{tabular}

Source: Data Processed

The coefficient of determination (R2) of the first equation on the packaging (X1) and information transparency (X2) variables resulted in 0.099 or $9.9 \%$. This first equation explains that the independent variable in explaining the variance in the dependent variable is $9.9 \%$ for the intention to try $(Y)$. This third equation explains that the independent variable in explaining the variance in the dependent variable is $66.1 \%$ for the intention to try $(\mathrm{Y})$ and the remaining $33.9 \%$ is obtained by other variables not included in this study. The R square change from the third equation has an increase after the multiplication of moderation, there is an increase of $0.562 \%$.

\section{The Influence of Packaging on Intention to Try}

This study shows that the packaging variable (X1) has an influence on the intention to try $(\mathrm{Y})$ of Cikake products. So hypothesis 1 is that packaging has an influence on the intention to try Cikake products is acceptable. The t test results resulted in a significance $(0.005<0.05)$, which means that there is a significant effect. Packaging a product that has the functionality to meet consumer needs and help consumers during the consumption process. The results of this study are consistent with research conducted by Imiru (2017), Adiyanto (2019) and Apriyanti (2018). Cikake's ricebowl-shaped packaging in terms of functionality is able to meet consumer needs. Judging from the functionality of packaging, it can be associated that packaging is a solution to attract consumer attention because packaging is directly related to consumers, of course packaging must keep up with the times by presenting packaging according to needs (Murfeni, 2016). 


\section{The Effect of Information Transparency on Intention to Try}

Based on the results of hypothesis testing using the $t$ test, it shows that the information transparency variable $(X 2)$ has an influence on the intention to try $(Y)$, so it can be said that the hypothesis of the effect of information transparency on information to try can be accepted. The significance of this variable is $(0.000<0.05)$ which means that there is a significant effect. The results of this study are consistent with research conducted by Purwanto (2017), Kim \& Lee, (2018) and Arceiz et al., (2018). Transparency information is information that is produced, stored or felt by consumers who see it, so the information produced must be accurate and correct and not misleading consumers (Asaloei et al., 2018). Through information disclosure to consumers, it can provide maximum information. The importance of completeness and openness of information on an e-commerce web can lead to a perception for consumers about the products being offered, so a company must be able to produce information transparency. Using Instagram is an effective way to deliver information and can be accessed by people who have Instagram. This means that Cikake consumers have received the information provided through Instagram and are able to influence their interest in trying.

\section{The influence of Information Transparency with Endorser Capability as moderation on Intention to Try}

The results of testing the information transparency variable (X2) with endorser capability $(\mathrm{Z})$ as moderation have significant results on the intention to try $(\mathrm{Y})$ variable. It can be seen from the $t$ test results show a significance of 0.030 which indicates that it is below 0.05, which means that it has a significant relationship. Looking at the test results of the coefficient of determination, there is an increase in the $\mathrm{R} 2$ value after adding the moderation multiplication results. This means that hypothesis 3, namely transparency information, has an effect on intention to try with endorser capability as moderation is accepted. The results of this study are in line with research conducted by Hani et al., (2018), Farid \& Dimeila (2019) and Mubarok (2016). Physical support generated by endorsers is able to provide good advertising evaluations compared to using communicators who are less attractive or known to the public. Endorsers certainly have to master the information about the product and convey it accurately so that it can be trusted by followers (Dewi \& Sulistyawati, 2018). The information provided by the endorser is one of the supporting factors for generating perceptions in consumers and the resulting memories.

\section{CONCLUSIONS AND SUGGESTIONS}

Packaging owned by Cikake is able to influence consumers to try the product and the high functionality of the packaging that is owned by a product can increase the attractiveness of consumers to try the products offered. The means used in conveying information are also very important so that the information conveyed can be received properly. The existence of transparency information on social media is able to provide deeper knowledge about Cikake products. Endorsers promote through social media and direct their followers to view Cikake's social media so that consumers can feel the transparency information given. Suggestions for further 
research are to be able to present reusable and environmentally friendly packaging. Using marketing using a different endorser. Expanding the scope of further research so that the data is more varied.

\section{REFERENCES}

Alger, E. D. (1989). The Media and Politics. New Jersey : Prentice Hall.

Andre, A., Marwan, A., \& Hani, S. (2018). The Effect of Celebrity Endorsement on Consumer Behavior: Case of the Lebanese Jewerly Industry. Journal of Arab Economic and Business, 190-196.

Apriyanti, M. E. (2018). Pentingnya Kemasan Terhadap Penjualan Produk Perusahaan. Jurnal Fakultas Bahasa dan Seni, pp. 20-27.

Arceiz, F. J., Pérezgrueso, A. B., Rivera, P., \& Moneva, J. (2018). The role of Corporate Governance and transparency in the generation of financial performance in socially responsible companies. Journal of Business Ethics, 1-48.

Baggozi, R. P., \& Warshaw, P. R. (1990). Trying to Consume. Journal of Consumer Research, 127-139.

Farid, \& Dimeila, S. (2019). Pengaruh Selebriti Endorser Instagram Terhadap Minat Beli Followers. Jurnal Manajemen \& Bisnis, 247-254.

Hardilawati, W. L., Binangkit, I. D., \& Perdana, R. (2019). Endorsement: Media Pemasaran Masa Kini. Jurnal Akuntansi dan Ekonomika, 88-98.

Hinz, V. B., \& Ployhart, R. E. (1998). Trying, Intentions, and the Processes by Which Goals Influence Performance: An Empirical Test of the Theory of Goal Pursuit. Journal of Applied Social Psychology, 1051-1066.

Imiru, G. A. (2017). The Effect of Packaging Attributes on Consumer Buying Decision Behavior in Major Commercial Cities in Ethiopia. Journal of Marketing Studies, 4354.

Industri, D. (2020). Tren Data Pertumbuhan Industri Penyedia Makanan Minuman, Restoran, dan Sejenisnya, 2010 - 2020. Retrieved from dataindustri.com: https://www.dataindustri.com/produk/tren-data-pertumbuhan-industri-penyediaanmakanan-minuman-restoran-dan-sejenisnya/

Jovita, C., \& Indika, D. R. (2017). Media Sosial Instagram Sebagai Sarana Promosi untuk Meningkatkan Minat Beli Konsumen. Jurnal Bisnis Terapan, 25-32.

Kertamukti, R. (2015). Strategi Kreatif dalam Periklanan: Konsep Pesan, Media, Branding, Anggaran. Jakarta: PT Raja Grafindo Persada. 
Kim, H., \& Lee, T. H. (2018). Strategic CSR Commucation: A Moderating Role of Transparency in Trust Building. International Journal if Strategic Communication, 107-124.

Korowa, E., Somayku, S., \& Asaloei, S. (2018). Pengaruh Kelengkapan Produk \& Harga terhadap Pembelian Ulang Konsumen. Jurnal Administrasi Bisnis, 27-34.

Mubarok, D. A. (2016). Pengaruh Celebrity Endorsement terhadap Minat Beli Konsumen (Studi pada Konsumen Mahasiswa Kelas Reguler Sore STIE INABA Bandung). Jurnal Indonesia Membangun Vol 15, No. 3, 61-76.

Murfeni, A. N. (2016). Pengaruh Desain Produk, Bentuk Kemasan dan bahan Kemasan terhadap Minat Beli Konsumen (Studi Kasus Teh Hijau Serbuk Tosca). Jurnal Ekonomi Manajemen, 49-54.

Ritonga, E. Y. (2018). Teori Agenda Setting dalam Ilmu Komunikasi. Jurnal Ilmu Komunikasi, pp. 32-41.

Rochyawati, F. (2017). Indikator Lingkungan Intern pada Kinerja Keuangan dengan Intellectual Capital dan Size sebagai Variabel Moderasi dan Mediasi. Jurnal Perilaku dan Strategi Bisnis, Vol. 5 No. 1 pp. 1-20.

Sartika, D. (2017). Analisis Faktor-Faktor yang Mempengaruhi Minat Pembelian Produk U C1000. Jurnal Penelitian Penelitian Ekonomi dan Bisnis, 10 - 21.

Stohl, C., Stohl, M., \& M, P. (2016). Managing Opacity: Information Visibility and the Paradox of Transparency in the digital Age. Journal of Communication, 123-137.

Teofilus, Sutrisno, F., \& Gomuljo, A. (2019). THE ELEMENTS OF PACKAGING THAT FORM A BRAND PERSONALITY (Study In Aroma Premium Sekoteng Products) . Jurnal Ilmiah Manajemen, 382-393.

Teofilus, Sutrisno, F., Hongdiyanto, C., \& Wananda, V. (2020). A Study of Indonesian Online Marketplace: Information Processing Theory Paradigm. Journal of Distribution Science, $75-87$. 